\title{
Smart Schools an Innovation in Education: Malaysian's Experience
}

\author{
Hassan Mirzajani $^{1}$ ¿ \\ Mehraneh Delaviz Bayekolaei ${ }^{2}$ \\ Meysam Rajaby Kookandeh ${ }^{3}$ \\ Seyede Safoora Razzaghpoor \\ Rezaee $^{4}$ \\ Ali Akbar Kamalifar ${ }^{5}$ \\ Hassan Razaghi Shani ${ }^{6}$
}

Faculty of Educational Studies, University Putra Malaysia

${ }^{2}$ Faculty of Education, University Malaya, Kuala Lumpur, Malaysia

Faculty of Humane Resoure Management, Islamic

Azad University, Gaemshahr Branch, Iran

${ }^{4}$ Master of Nahjolbalaghe, Islamic Azad University, Azadshahr Branch, Iran

${ }^{5} \mathrm{Ph}$.D Candidate of philosophy in management, Lincoln University in Malaysia

${ }^{6}$ Department of Management Lincoln University

College Malaysia, Branch Iran

( Corresponding Author)

\begin{abstract}
According to the new environment created by the information period, training and learning new skills are being inevitable. Retraining the skills of group working to coordinate the information age has created special conditions for education. Smart schools are one of the strategies adopted by schools in response to today's modern needs. Smart schools are active for entrepreneurship, using modern methods to improve the quality of education, and training qualified people who at any time have the capability and efficiency of modern industry. The purpose of this study, is the use of ICT in Malaysian Smart School and comparing it with the Smart Schools in Iran. To conduct this study, library, documents, Web sites and electronic journals are available. The results of this study show that although there are significant differences between the education system and deployment of ICT in Iran with the standards in smart schools in leading countries like Malaysia, according to the original development of smart schools in Iran which has been adapted from Malaysia, recognizing the realities of this action in Malaysia, can be effective in the development of schools in the country and prevent indiscriminate development.
\end{abstract}

Keywords: Smart schools, ICT, education, Malaysia, Iran.

\section{Contents}

1. Introduction

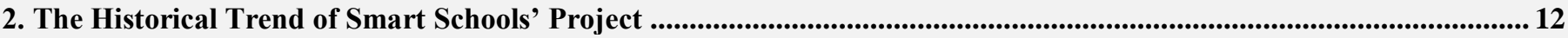

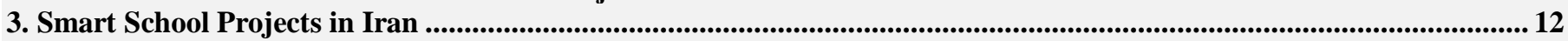

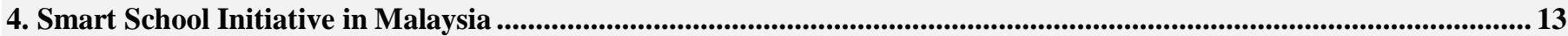

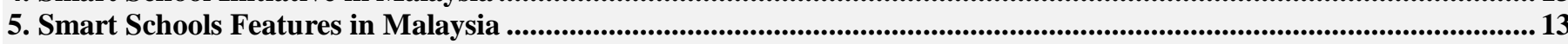

6. Obstacles and Challenges of Smart Schools: Malaysian Experience ...................................................................................... 14

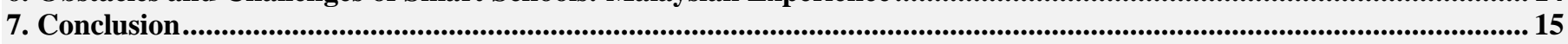

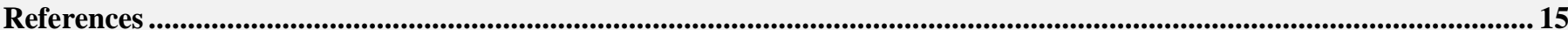

Citation | Hassan Mirzajani; Mehraneh Delaviz Bayekolaei; Meysam Rajaby Kookandeh; Seyede Safoora Razzaghpoor Rezaee; Ali Akbar Kamalifar; Hassan Razaghi Shani (2016). Smart Schools an Innovation in Education: Malaysian's Experience. Asian Journal of Education and Training, 2(1): 11-15.

DOI: $10.20448 /$ journal.522/2016.2.1/522.1.11.15 Zcrossref

\section{$(\mathrm{cc})$ EY}

This work is licensed under a Creative Commons Attribution 3.0 License

Asian Online Journal Publishing Group 


\section{Introduction}

The use of ICT in education has many advantages and can provide more effective and deeper knowledge to the students. The impact of information and communication technology (ICT) in various aspects of life is so fundamental that distinguishes our era by past era. What distinguishes today's nations is the utilization and application of ICT more than any other factor. New technologies free students and teachers from the traditional learning environment of schools and certainly reduces the control of teacher on students' thinking, feeling and behavior (Mirzajani et al., 2015). This increases learning motivation and makes students to be active, creative and effective. Their desire to gain information and knowledge increases and naturally training can be on the actual track (Ebadi, 2004).

Of course, the key element of progress in the modern societies is education. If the education system gets busy with theoretical arguments and continue with old and inefficient methods, certainly all aspects of society will face with pervasive recession. Entering the information age and the prevalence of technology-based global networks and computers would create a new formal and non-formal learning environment. Smart school is one of the adopted approaches to meet today's modern needs (Millton, 2003). Smart Schools is an educational approach that will lead to fundamental changes in learning and teaching process with the integration of information technology and curriculum, in the approach teacher has the role of a guide, not a transferor of knowledge, and the role of students rather than passive consumption of organic knowledge is as an active, creative, critical and participation person. Evaluation system changes a process-driven inquiry (Attaran, 2011). Smart schools are the major achievements in the development of information technology in education programs that not only influences educational environments but also it will be a development with real experiences for students and their tomorrow life. Smart School is a practical and targeted offer to run the most advanced and new teaching methods and scientific look at the current state of the educational system (Yoong and Lew, 2009).

\section{The Historical Trend of Smart Schools' Project}

In 1984, Perkins and his colleagues at Harvard, offered smart school project as a new experience in education programs by ICT. According to Perkins (1992) in smart schools two important points should be borne in mind, one is that learning is the product of thought and all students can learn well thought, and that learning requires deep understanding and flexible and active use of knowledge. This scheme was implemented gradually in a number of school and later expanded somewhat. Many developed countries use these schools to train their human resources development programs (Madras, 2011).

Perkins (1992) believes that seven basic principles are necessary to smart schools, the management of the school and its staff: generated knowledge: useful choice of lessons for students; conception of intelligence as something acquired and achieved and not a fixed attribute; emphasis on understanding; tutorials to learn and not exam; assessment to learn and not exam; the role of School as a learning organization; dealing with complex situations.

The so-called smart schools inclusively, was raised the first time in Malaysia in 1996 with a focus on preparing students to enter the information age and accordingly, drastic changes were considered in Malaysian schools and believed that ultimately All schools become Smart. In these schools learning is based on the speed of the individual, partnership, self-coherence between the subjects and the course content is not limited to printed books but also ebooks, software, multimedia courseware and databases. Simultaneously some plans are being prepared for individual differences in learning styles of each student. The project was launched in 1999 and pilot implementation completed in 2002 (Attaran, 2011).

Singapore is another Southeast Asian country that uses ICT methods in education. In 1997, the first large-scale initiative was developed in order to make use of ICT in education infrastructure and equipping teachers with the skills they need for the use of ICT in their lessons. The second major project for the use of ICT in education (20032008) was more about infrastructure and the integration of ICT with teacher training schools. Finally, the third Master Plan (2009-2014) on the integration of ICT with curriculum, emphasizes training and evaluation. The plan is based on the belief that ICT, encourages students in any place and time to search for self-learning and experiential learning and increases them for the 21 st century learning (Singapore Ministry of Education, 2011).

\section{Smart School Projects in Iran}

Smart School project was launched in 2003 in Iran with inspiration from the original idea in Malaysia. Shahid Aghayee was a non-profit school who taught with the use of audio-visual technology. The founder of the school later carried out similar school projects in Yazd and Qazvin province in public high schools (Attaran, 2011). In 2004, four public high schools in Tehran, smart school project was implemented as a pilot project by the Education Ministry in Tehran. In 2007, after three years of implementation of the smart school pilot in Tehran, smart schools began and teachers were taught based on the strategic plan of the project. For the realization of smart schools in this project 100 schools were chosen by Ministry of Education, 50 were part of high schools in different provinces of the country (Omidinia, 2009). Education institution in Tehran in 2010 published a book with the title of "roadmap of smart schools "where in addition to the Smart School goals, how to implement smart schools and their evaluation model were presented. In 2011 the Ministry of Education changed some schools into smart schools in most major cities in Iran. This project seeks a Master Plan which was chosen by education institution for development of ICT in Iran. In fact, officials of Education gradually came to a deeper understanding of global developments and the role of ICT in development (Attaran, 2011). This led to the development of ICT in this phase as a general direction taken by the managers of education. In 2009 the road map of smart schools which was developed by the Ministry of Education of Iran, smart schools have been mentioned as one of the key requirements of knowledge-based societies through the development of knowledge and entrepreneurial skills of students in these schools. Objectives and activities of the schools are based on the Malaysian Smart School but the sub structure are different in two countries. 


\section{Smart School Initiative in Malaysia}

The Smart School in Malaysia was established in fact Malaysia is the initiator of the project. The Malaysian government for its 2020 Vision, considered a plan as large multimedia corridor (MSC) and an electronic city to provide the country's entrance in information age (Bajunid, 2008). Smart School project was one of the seven great design by MSC. In 1997 government statement on the matter reads as follows: Malaysia needs a serious transition from an industrial country to a leading Country in the information age. Malaysia should become a country with deep technological literacy. And it also needs Labor force thinking that we have to work in the global economy and the skills to use the tools of the information age. To achieve this transformation, a transformation of the educational system should be maximum (Bajunid, 2008).

Smart Schools program focuses on the establishment of the infrastructure of ICT in the education system which consists of virtual network equipment, data center and software packages based on the teaching and learning of four subjects of "national language", "English," "science" and "mathematics" in Malaysian schools, in this way, the Ministry of Education in Malaysia and smart schools are better connected. These schools have a computer integrated management system that covers the whole range of tasks and smart schools. The purpose of this work is to reinforce the use of ICT in primary and secondary schools with a radical change in the educational system through the restructuring teaching-learning process that by the integration of ICT in the lesson plans, education and assessment methods, teaching and learning become attractive (Yoong and Lew, 2009).

Malaysian Smart School project was launched in January 1999 and the experiment ended in 2002. In the pilot project, 78 million dollars was considered and the largest share of $38 \%$ of the budget was devoted to the preparation of training materials (Puteh and Vicziany, 2004). At the end of this experience, it was decided that such schools have to be designed based on the following elements:

- Search-based curriculum and related materials written for courses in Malay, English, science and mathematics.

- Computer management systems of Smart Schools.

- technology infrastructure of smart schools involves the use of IT and non-IT equipment, local area network and virtual private network with the ability to connect the pilot schools, data centers and services of the Ministry of Education.

centralized support centers across the country to support and maintenance. - Specialized support such as integrated systems, project management, re-engineering business process and change management (Foong, 2002).

Malaysia Ministry of Education (1997A) described five features of smart school curriculum as below: Holistic training and education that emphasizes thinking skills, effective communication skills and emotional, cognitive and social development; Integration of life skills, language and moral values knowledge; Integration of vertical evaluation method; Integration of multidisciplinary and interdisciplinary curriculum; Integration of technology as a tool in the teaching and learning process (Ya'acob et al., 2005).

\section{Smart Schools Features in Malaysia}

Smart school students take advantage of the Internet to access information and resources for getting answers to their questions in addition to the communication with class teacher other and students. Content is provided in an electronic form and the teacher is a guide. The school is trying to help new technology learning difficulties such as problems related to lack of computer literacy, information literacy, teaching and problems associated with the traditional methods. The following can be noted as other features of these schools.

\subsection{Curriculum}

Curriculum in smart schools should be meaningful. This program must develop a sense of responsibility in students so that they become aware of their duties as a citizen. Other features of this program reflects the skills and attitudes that enable them to think critically, creatively and be positive. Comprehensive curriculum, creates an opportunity for all aspects of human intelligence and help students to see the connections between different subjects. In addition, the smart school curriculum is aim-centered and the objective is that all students develop their critical skills and knowledge they need to live as a citizen (MME, 1997B). In total, the smart school curriculum promotes holistic learning and creates opportunities for student achievement and talent and at the same time concerns the interests and needs of the students (Attaran, 2011).

\subsection{Evaluation}

Smart school evaluation system should be such that provides a more accurate picture and a comprehensive evaluation of the performance of the students. In this system, teachers, students and parents can access to various parts of the evaluation via the Internet (Madras, 2011). The purpose of the evaluation in the schools is the realization of the philosophy of education, therefore, a comprehensive and accurate picture of the performance of students is required. In this system, teachers, students and parents have online access to the evaluation questions. Smart Schools' evaluation system is flexible, familiar and easy to use for learner. The information obtained from the evaluation has appropriate credit. Evaluation of students in such schools is done every day, consistently, on line and on distance. Parents can also be connected with a simple instruction to school evaluation system and thereby informed of the status and progress of their child's education. Usually at these schools at the end of the class an E-Mail will be sent from the school to inform parents of their children's education situation.

\subsection{Content and Learning of the Curriculum}

Smart schools need new content, well designed and innovative methods of teaching for teaching and learning. Such programs will supply the needs of students with different abilities, and thus reveals capabilities and give the opportunity to students to accept more responsibility for managing and directing their own learning. Teachers in such 
schools can use databases and software programs and other new courses designed to suit the needs and interests of students and change or modify the content of the courses in the schools. Therefore, the learning content will be somewhat different from other schools.

\subsection{Teachers}

The role of teachers in such schools is largely changed from teaching and evaluation of students to track their personal training and thus the opportunity and more time to address their professional growth and development programs (study, constructive communications and interactions, promoting their knowledge and teaching skills and ...). So for the effectiveness of the plan smart schools need trained and skilled teachers and administrators and welldesigned processes to support themselves (MME, 1997B).

As the Malaysian smart school project team stated, teachers' professional development is crucial to the success of smart schools. Training teachers need to use information technology and its integration with classroom activities to enhance thinking and creativity of the students. At the same time, teachers need to be smart in order to facilitate and encourage students to learn better, and in the long term, they need to increase their skills for the use of technology in education (MME, 1997A).

\subsection{Technology at School Level}

Technology has diverse roles in smart schools; such as teaching and learning process to help manage the schools. According to the team, equipping schools include the following:

- Classrooms with multimedia courseware and e-mail for teamwork;

- Library or Media Center multimedia software with a central database for studies and network resources such as access to the Internet;

- Computer laboratory and audiovisual equipment;

- A studio with a centralized control room for audio-visual equipment, video conferencing Chamber, workout sound and image studio;

- Teachers' room with online access to lesson plans and detailed content of each subject and databases, information and resource management systems, advanced communications tools, such as e-mail;

- Management room with the ability to manage databases and students' facilities, track student and teacher performance and the distribution of leaflets and other electronic information;

- Server room equipped to access applications, database management and network servers, security, telecommunications and access to network resources (MME, 1997A).

\section{Obstacles and Challenges of Smart Schools: Malaysian Experience}

Studies show that the development of smart schools in Malaysia has been successful in its technology part but the training has progressed slowly. Teachers resist to such schools and are not prepared to teach in such schools. They also worry that the insistence on the use of ICT in teaching, increase the amount of work (Puteh and Vicziany, 2004).

Yoong and Lew (2009) in this regard, reported that in most schools, teachers do not have sufficient skills in the implementation of ICT applications. A number of studies on the implementation of the pilot phase showed that the integration of ICT in the Malaysian classroom is still in the early stages and a lot of teachers are able to use ICTbased educational strategies, while for the successful implementation of the project, Preparation of teachers and schools, was a key issue. Although the Ministry of Education in Malaysia held short-term and intensive courses for teachers, but research has shown that these efforts did not help to improve the ability of teachers to implement ICT in teaching because they believe that almost half of teachers they have been able to reach half of their goals by internal training (MDC Smart School Department, 2005).

The study of Ali et al. (2009) about smart schools pointed out that teachers were facing problems during the process of integrating ICT in schools. Difficulties integrating ICT in Malaysian smart schools include: the time factor, unrelated course content and technological failure. In addition, the teachers complained that their free time was not enough to prepare for the course in which the use of ICT was a must. It takes time to Surf the Internet, search for information, review and selection of information. The findings also show that some teachers with lack ICT skills feel that to save time they can teach more content with more traditional methods, finish the curriculum and succeed in National examination.

In addition to this research Yoong and Lew (2009) also suggest that these schools' support costs has increased. The school management has been over-reliance on ICT and everyday human interaction between the collection of teachers and management decreases. The new philosophy of smart schools says teachers must use teamwork, talk less and take advantage of a wide range of educational activities and learning with ICT applications. Of course search, design and synthesis of new materials suitable for learning environment are time consuming. In addition to the normal working hours of teachers in school they have to spend more hours in school to complete their tasks. However, they are not given any reward for this work. For the realization of the smart school concept, teachers should have a very high commitment. The arrival of ICT in smart schools must conjugate with the use of interactive educational lesson that combine sound, graphics and animation in such a way that students find their ability to explore and construct knowledge. Funding for this application is essential. Pilot Smart school administrators have complained about the non-allocation of funds for the purchase and preparation of required software.

Research reports indicate Iran has more or less similar problems. Mahmoudi et al. (2008) in their study consider the basic challenges of smart schools as below:

- The lack of rules and regulations required by the Ministry of Education of Iran, with respect to the issue that in smart schools, control, monitoring and evaluation is done in an intelligent computer-based technology. Lack of regulation in this area is causing problems at school. For example, teacher is not responsible for creating multimedia 
content and if a teacher prepares the content for personal interests, there is no legal basis for the payment of financial compensation.

- Lack of infrastructure, internet connectivity, hardware, PC, and lack of adequate resources in schools, which has led to one of the most important challenges.

Incompatible relationship between structure and organization of schools, a structure in which information technology has no place. Noting the crucial role of information technology in smart schools, the need to fit specific organizational structures of schools with information technology is felt. Attaran et al. (2012) research reports suggest that despite many material resources allocated by Ministry of Education on the development of smart schools, the results do not match expectations.

\section{Conclusion}

One of the most important features of the present period is momentum of scientific, technological, and social developments. Almost in all countries it is expected that the Ministry of Education be the source of changes and innovation. This means that the education system should also align itself with the development of modern society and the changes and predict future changes and in order to create favorable developments in the future for guidance. In this regard, one of the approaches that can be beneficial to meet the requirements within the educational system and in many developed countries have implemented or are being implemented, is the use of information and communication technologies in the educational system and consequently the establishment and development of smart schools. These schools were actually a new concept and philosophy of education and by abandoning the traditional series of inhibitors, they try to use information technology to provide training. Malaysia has a national policy and master plan for infrastructure and ICT integration in education. Effort and many resources have been spent on smart school project. Providing or improving infrastructure and ICT facilities in schools are only one step to go a long way towards integrating ICT with education at schools. However, there are many potential abilities to stimulate educational systems in support of the integration. Some of the initial steps in that direction are equipping schools with ICT infrastructure, training teachers and administrators to gain expertise and familiarity with basic applications of ICT and software development courses. As regards ongoing training for teachers and administrators with a range of ICT applications and giving them time to enhance their confidence is a priority. Case studies show that with proper and pre-planned training, teachers and students can be motivated to Internet resources for teaching and learning effective and interactive benefit (Yoong and Lew, 2009). As a result, and According to the original development of smart schools in Malaysia, recognizing the realities of this action in Malaysia, can be effective in the development of schools in the country and preventing excessive development is effective. So for the effective and efficient utilization of information technology, especially in the development of education we need to improve approaches, review education policy, reorganization of content, improvement of human resources and curricula designed to provide effective and evolution of cultural norms coexist with novel technology.

\section{References}

Ali, W.Z.W., H.M. Nor, A. Hamzah and N.H. Alwi, 2009. The conditions and level of ICT integration in Malaysian smart schools. International Journal of Education and Development using Information and Communication Technology (IJEDICT), 5(2): 21 - 31.

Attaran, M., 2011. How and why smart schools. Journal of Teacher Development, Publications of Training Research and Planning, Ministry of Education. Iran, 7: 2-4.

Attaran, M., S. Saedah and A. Norlidah, 2012. Learning culture in a smart school: A case study. Working Paper at International Educational Technology Conference (IETC 2012). Taoyuan، Taiwan.

Bajunid, I.A., 2008. From traditional schools to smart schools: The Malaysian educational Odyssey. Kuala Lumpur: Oxford Fajar.

Ebadi, R., 2004. E-learning. Tehran: Amir Kabir Publications.

Foong, C.M., 2002. ICT in Malaysian schools: Policy and strategies. In a Workshop on the Promotion of ICT in Education to Narrow the Digital Divide. pp: 15-22.

Madras, S.A., 2011. Smart schools. Tomorrow School's Roshd Journal, Publications Training, Research Planning, Ministry of Education. Iran, 20: 7-18.

Mahmoudi, J., S. Nalchigar and S.B. Ebrahimi, 2008. The challenges of smart schools in Iran. Iran: Publication of Educational Innovations.

Malaysia Ministry of Education, 1997A. The Malaysian smart schools implementation plan. Kuala Lumpur, Malaysia: Smart School Project Team, Ministry of Education.

MDC Smart School Department, 2005. Malaysian smart school roadmap 2005 - 2020: An educational Odyssey - A consultative paper on the expansion of the smart school initiative to all schools in Malaysia. Cyberjaya: Multimedia Development Corporation.

Millton, P., 2003. Trends in the integration of ICT and learning in k-12 system. CA: Canadian Education Association.

Mirzajani, H., K. HajiAlizadeh, O.H. Gorji, S.E.O. Mohammadi, R. Sohaei and M.D. Bayekolaei, 2015. The need for recognition and implementation of educational technologies by teachers in the educational and learning process. International Journal of Learning and Development, 5(3): 14-24.

MME, 1997B. The Malaysian smart school: A conceptual Blueprint. Kuala Lumpur, Malaysia: Ministry of Education, 11 July 1997.

Omidinia, S., 2009. Development of ICT strategic plan for smart school in Iran (Case Study: Ministry of Education in Iran). Masters Thesis ، Universiti Teknologi Malaysia، Faculty of Computer Science and Information Systems.

Perkins, D.N., 1992. Smart schools: From training memories to educating minds. New York: The Free Press.

Puteh, M. and A. Vicziany, 2004. How smart are Malaysia's smart schools? In 4th Global Congress on Engineering Education (UNESCO International Centre for Engineering Education (UICEE) and King Mongkut's University of Technology 5 July 2004 to 9 July 2004 ). pp: 223-228.

Singapore Ministry of Education, 2011. Education in Singapore: Finding from international benchmarking studies. Singapore: Ministry of Education.

Ya'acob, A., N.N. Mohd and H. Azman, 2005. Implementation of the Malaysian smart school: An investigation of teaching-learning practices and teacher-student readiness. Internet Journal of e-Language Learning \& Teaching, 2(2): 16-25.

Yoong, S. and L.Y. Lew, 2009. Enhancing ICT application in science and mathematics education: The Malaysian smart school experience. Multiple Literacy and Science Education: ICTs in Formal and Informal Learning Environments: ICTs in Formal and Informal Learning Environments, 142 